\title{
Population-Level Predictors of STI Rate Changes in Missouri From 2008-2017
}

Ella Valleroy ( $\nabla$ evalleroy@kumc.edu )

University of Kansas Medical Center https://orcid.org/0000-0001-6906-9469

Aaron Reed

University of Missouri Kansas City

Joseph S. Lightner

University of Missouri Kansas City

Research

Keywords: sexually transmitted infections, population health, Missouri, HIV

Posted Date: September 29th, 2021

DOI: https://doi.org/10.21203/rs.3.rs-922268/v1

License: (1) This work is licensed under a Creative Commons Attribution 4.0 International License.

Read Full License 


\section{Abstract}

\section{Background}

Sexually transmitted infection rates continue to increase across the US, further developing health disparities and economic burdens of disease, especially as migration occurs. In this study, we assessed the relationships among STI rates and migration at the county-level in Missouri from 2008-2017.

\section{Methods}

Two data sources were used: STI rates of chlamydia, gonorrhea, syphilis, HIV reported to Missouri DHSS and ACS 1-year county population estimates. Linear regression models and ANOVA tests were conducted in SPSS for each STI from year-to-year and 2008-2017. Covariates included in the analyzes were countylevel income, employment rate, race, ethnicity, age, and percent poverty. Further, Akaike Information Criterion tests were performed to indicate the best predictor models and averaged standardized beta values.

\section{Results}

Significant relationships among STI rates and population growth were identified. Chlamydia, syphilis, and HIV were positively associated with population growth from 2008-2017 $(\beta=0.15 ; \beta=0.01 ; \beta=0.05$, respectively). Gonorrhea was negative associated with population growth $(\beta=-0.02)$ but positively associated with unemployment rates $(\beta=0.01)$ highlighting the need to address population growth, as well as other variables in a population.

\section{Conclusions}

There seems to be a positive relationship among population change and rates of STIs. As populations change, rates of STIs change. Moving forward, quantitative work should be conducted in various states and the nation to understand this relationship in different contexts. Qualitative studies should assess individual county health departments, identifying strengths and weaknesses, implementation of community health improvement plans. Lastly, public policy should be implemented to buffer the impact of migration on health outcomes.

\section{Background}

Sexually transmitted infections (STI) continue to pose a complex, significant, and constantly evolving public health concern in the United States. ${ }^{1}$ In the Midwest from 2016-2017, the chlamydia rate increased $5.6 \%$, the gonorrhea rate $19.5 \%$, and the syphilis rate $8.8 \% .^{1,2,3}$ This increase is attributed to more widespread screening, reporting, and cases altogether. ${ }^{1}$ Other factors include more sensitive and accurate diagnostic tests, like nucleic acid amplification tests (NAATs). ${ }^{1}$ A small percentage increase indicates a significant amount of new cases and subsequent healthcare costs as more are being screened and 
treated. ${ }^{1}$ HIV incidence has declined in recent years due to extensive preventative campaigns but has now plateaued as specific high-risk groups such as transgender persons, men who have sex with men, African American, and Latinos, are not being adequately reached, especially in the South. ${ }^{4}$

There are serious implications if infected individuals go unscreened and untreated after contracting STIs. The reasons for not seeking diagnosis and treatment can be complex. Marginalized ethnicities, individuals that may experience racism, homophobia, and xenophobic interactions, and impoverished populations, have the lowest access to healthcare and screening tests, placing them at high risk of acquiring STIs. ${ }^{5}$ Drug use also increases risk of STI contraction, along with unplanned pregnancies. ${ }^{6}$ More specifically, methamphetamine use, a known problem within Missouri, increases libido and risky sex among its users. ${ }^{6}$ Finally, group sex or sex with multiple partners can increase risk of transmission. ${ }^{7}$

Some STIs can manifest asymptomatically more so in women and cause them to go unscreened and untreated for longer than men who typically develop symptoms faster and more noticeably. ${ }^{8}$ For this reason, women often suffer more severe, long-term complications from STIs, some including chronic pelvic pain, ectopic pregnancies, and infertility. ${ }^{8}$

Between screening, treatment, and long-term management of STIs, the estimated financial burden in the United States is around $\$ 15.6$ billion. ${ }^{9}$ Chlamydia and gonorrhea account for $\$ 516.7$ million and $\$ 162.2$ million respectively, while syphilis accounts for $\$ 39.3$ million, and HIV for $\$ 12.6$ billion. HIV accounts for $81 \%$ of the total annual cost of STIS in the US. The overall increase in STI cases has not been limited to a single social group, age group, gender, or socioeconomic class. ${ }^{7}$ These costs may change as STIs shift, such as the emergence of multi-drug resistant gonorrhea. ${ }^{10}$ Although data over the cost of STIs within Missouri is unknown, in 2016, the CDC provided $\$ 6.8$ million in funding specific for HIV/AIDs prevention and treatment and an additional \$2.2 million in funding specific for other STIs. These values may be subject to change as multi-drug resistant gonorrhea becomes more prevalent. ${ }^{10,11}$ Antibiotic resistant gonorrhea has the potential to become an incurable, chronic disease resulting in disability and death in a previously easily curable infection, highlighting the need to research and intervene in STIs at a population-level now. ${ }^{12}$

It is known that increased levels of unemployment can cause lowered income for individuals and families. ${ }^{13}$ Increased poverty levels have been linked to increased practice of risky sexual behaviors, like using a condom inconsistently or never, not using oral contraceptives, or other forms of birth control, while also having more sexual partners and 'one-night stands'. ${ }^{13}$ These behaviors increase risk of both encountering and contracting an STI. ${ }^{13}$ Here, it can be seen that population-level variables, or macro effects, can effect STI rates and spread as populations continue to change and encounter different situations.

Social epidemiology, a research methodology and theoretical framework that focuses on social determinants, practices, and health outcomes, provides an appropriate framework to address the factors 
that impact STI rates. Macro effects on disease and STI transmission are often ignored and instead the focus is put on individual risk factors. ${ }^{7}$ Social epidemiology defines three levels to the spread of STIs throughout society: 1) individual components, 2) social components, and 3) structural components. ${ }^{14}$ Individual components involve biological susceptibility and risky behaviors. Social components involve networks, communities, and how disease diffuses across populations. ${ }^{14}$ The structural components are grouped into 1) cultural context, 2) social networks, 3) neighborhood effects, and 4) social capital. Social epidemiology can be used as a lens to understand the impact of population change and STI rates within a state. Social epidemiology lacks the insight of an individualized point of view on STIs, but the majority of data focuses on individual trends. ${ }^{7}$ It instead provides insight into large-scale trends affecting many with STIs, where data may be less extensive but equally compelling due to the vast amount of individuals it can then reach. ${ }^{7}$

Given the social complexity and financial cost of STIs, it becomes critical to monitor changing rates of these infections not only throughout static populations but also as moving populations change proportions of age, gender, ethnicity, and sexuality. With these changing dynamics, estimated risks of STI transmission fluctuate as different groups have different risk factors surrounding STIs. ${ }^{7}$ As populations grow and move, the incidence of STIs is expected to grow, showing the importance of population-level predictors alongside individual interventions. Moving, changing populations face problems of isolation and loneliness after relocating. ${ }^{12}$ It has been observed that moving populations typically experience a higher risk of contracting STIs. ${ }^{15}$ Characteristics of a moving population include the social disruption that accompanies geographic relocation and a lack of access to health resources. ${ }^{15} \mathrm{ST}$ Is have remained persistent within society, in part, due to failure to contact trace all sexual partners of STI patients. ${ }^{9}$ This is possibly due to geographic or networking barriers, consistent with a moving population. Young people and those seeking secondary education most often have to relocate, particularly from rural to urban areas. ${ }^{16}$ In the past, the urban population of the world has increased much more quickly than those of the rural population. ${ }^{12}$ This is expected to remain the trend into the future as the United Nations expects the world population to increase to 9.1 billion by 2100 with urban population continuing to increase in population size, and rural populations moving more towards urban areas. ${ }^{12}$ Urban populations were considered the only "high-risk" areas for STI spread in the past, but new pockets of widespread infection in less densely populated areas have begun to form. ${ }^{8}$ In this study, we analyze the relationship among common STIs and population change at the county level in the state of Missouri from 2008-2017.

\section{Methods}

Data were accessed from the Missouri Information for Community Assessment (MICA) by the Missouri Department of Health and Senior Services (DHSS) regarding county-level data on age between 15-44, sex, race, and ethnicity every year from 2008-2017. ${ }^{17}$ Non-census year data comes in conjunction with the Federal State Cooperative Program for Population Estimates and the National Center for Health Statistics, alongside the US Census Bureau. Census year data, 2010 only, were taken directly from the US Census 
Bureau. Incidence of the three STIs: chlamydia, gonorrhea, and syphilis was compiled from the DHSS for the same time.$^{18}$ Chlamydia, gonorrhea, and syphilis are all infections that, when detected as positive in a hospital or clinic, must be reported to the county health department that the positive test originated from. These rates are then reported to the Missouri state health department for monthly and yearly reports. ${ }^{18}$ Incidence and prevalence of HIV was obtained through Geographic Information System programming by the Centers for Disease Control and Prevention from the years 2008-2016. ${ }^{19}$ At the time of this analysis, 2017 data were not available to the public. Data on county-level households living below the poverty level was recorded from the Small Area Income and Poverty Estimates (SAIPE) Program through the Census Bureau. ${ }^{20}$ All data were exported into Excel and SPSS (version 2009, version 25) for analysis.

Percent change in STI rates for chlamydia, gonorrhea, syphilis, HIV prevalence, and diagnoses were calculated from 2008 to 2017 for each county. The formula used to calculate and report population change was [(2017 County Cases / 2017 County Population) - (2008 County Cases / 2008 County population)] / (2008 County Cases / 2008 County Population). This was calculated and turned into a percentage within excel then exported into table 1.

Using population change as the independent variable, unadjusted multi-variate linear regression models were conducted with HIV prevalence and incidence of HIV, syphilis, gonorrhea, and chlamydia as dependent variable year-to-year and from 2008-2017 in SPSS (version 24).

Further statistical analysis was conducted in the R project in which Akaike Information Criterion (AIC) tests were conducted to determine if population growth was contained within the best change predictor models for each STI over the period of 2008 to 2017. The Akaike information criterion is a statistical test used to find the best change predictor models in datasets when multiple possible variables are being examined. Use of the AIC as a model fit test has been used previously in research surrounding STIS propelling it to be selected for further analysis in this study in order to find the best fit predictor model for the change in STI rates over the 10-year timeframe. ${ }^{21}$ These variable combinations are considered significant and equally qualified predictor models if the $\triangle \mathrm{AIC}$, or change in Akaike Information Criterion, value is below two. Of those found to be similarly qualified change predictor models, the weights, or $\mathrm{w}_{\mathrm{i}}$, and $R^{2}$ values can then be further calculated to predict the likelihood of the significant models being classified as the best change predictor model in the dataset. ${ }^{22}$ All models predicted to be of best fit gave similar $w_{i}$ and $R^{2}$ values, showing that each model can be a good predictor in the future change of STIs. Note that a small alteration was made to the analysis with HIV being reported as total cases for the years of 2008 and 2017, instead of the two distinctions of incidence and prevalence to allow for a larger, more significant sample size

\section{Results}

Table 1 presents the percent change of study variables from 2008 to 2017, including: race/ethnicity, average household income, average unemployment rate, and population size. Most counties showed a 
negative percent change in white individuals and average unemployment rates and a positive percent change in African American individuals and Latinx individuals. Table 2 shows the percent change in STIs from 2008 to 2017. Most counties showed considerable percent increases in chlamydia, gonorrhea, and syphilis. The counties show mixed positive and negative percent changes regarding HIV, possibly due to the limited sample sizes.

Table 3 shows the results of the linear regression among STIs and population change between 20082017. The association between population change and chlamydia $(\beta=0.60, p<0.05)$, gonorrhea $(\beta=0.50$, $p<0.05)$ and syphilis $(\beta=0.2, p<0.05)$ showed a significant positive association. HIV diagnoses from 20152016 was positively associated with population change $(\beta=0.30, p<0.05)$. HIV prevalence showed a similar positive association $(\beta=0.03, p<0.05$ ). As populations increase or decrease in counties in Missouri, rates of STIs increase and decrease too.

Table 4 displays the results from the Akaike information criterion test (AIC) with the significant change predictors bolded for each STI.

Table 5 further shows the model average beta values which can be interpreted to show the future change in STIs per unit of the variables included in the models. Population growth showed a positive value in chlamydia $(\beta=0.15)$, syphilis $(\beta=0.01)$, and HIV $(\beta=0.05)$ and a negative value in gonorrhea $(\beta=-0.03)$. Unemployment, which also appears in each STI's change predictor model, showed a positive change for chlamydia $(\beta=0.02)$, gonorrhea $(\beta=0.01)$, syphilis $(\beta=0.001)$, and $\operatorname{HIV}(\beta=0.02)$.

\section{Conclusions}

This study identified several relationships between common STI rates and population change across Missouri at the county level. A positive relationship exists between population change and STI rates. This study also shows that population growth and size are as integral to predicting the change in STIs as other structural-level functions, like income and unemployment which may already be considered when evaluating future STI rates and change. As populations change, rates of STIs change.

Population growth and total HIV cases showed a positive relationship through model average standardized beta values $(\beta=0.05205)$. If we extrapolate these results to predict future cases, we would expected 52 newly-diagnosed or existing-when-moving-into-the-county cases of HIV if the population of a county grew by 1,000 people. The lifetime cost of a single case of HIV is estimated as $\$ 304,500$ in medical expenses. ${ }^{9}$ An increase in 52 new cases of HIV would cost a county $\$ 15.83$ million more in healthcare expenditure.

Population growth was positively associated with chlamydia such that an increase of 152 cases may occur per additional 1,000 people $(\beta=0.15206)$. This adds $\$ 29,550$ total in additional costs, if the cases are treated successfully after initial infection. ${ }^{9}$ Costs increase to $\$ 3.5$ total million when considering sequalae costs in asymptomatic cases. A large cost disparity exists between male and female cases, highlighting the need to intervene on those infected before chlamydia can spread in a county. ${ }^{9}$ 
Population growth was positively associated with syphilis such that an increase of 7 cases may occur per additional 1,000 people. This adds $\$ 4.963$ in additional costs per 1,000 people for treatment of syphilis $(\beta=0.00664) .{ }^{9}$ Costs increase significantly and vary in reflection to the syphilis progression. The cheapest option after syphilis contraction, is immediate treatment before possible disease progression.

Population growth was negatively associated with gonorrhea such that a decrease in 27 cases may occur per additional 1,000 people $(\beta=-0.02705)$. Interestingly, unemployment was positively associated with gonorrhea such that an increase in 12 cases may occur for 1,000 additional unemployed individuals $(\beta=0.01224)$. This adds $\$ 2,598$ in direct medical care. Sequalae costs are estimated near $\$ 3.5$ million with a large cost disparity existing between men and women. ${ }^{9}$ This cost should be investigated further with the emergence of multi-drug resistant gonorrhea. ${ }^{10}$ This difference in conclusions between variables highlights the need to consider multiple variables when evaluating the future of STIs. There is no single variable that can accurately predict the future change in STIs without fail. Population growth and size as well as unemployment and income must all be considered when predicting the future of STI rates.

Table 1 shows the percent change in STI rates from 2008 to 2017 while controlling for population change. The change is predominantly positive, meaning that even as the population is increasing, STIs are increasing at faster rates than the population. Generally larger counties, like Jackson or St. Louis county, displayed smaller percent changes. For example, the most prevalent STI, chlamydia, had a $0.15 \%$ and $20.13 \%$ increase in Jackson and St. Louis county respectively. Smaller counties displayed significantly larger percent increases. For example, chlamydia cases increased $246.54 \%$ and $142.05 \%$ in Ste. Genevieve and Stone county, respectively. This shows that STIs are a problem for both small and large counties and are growing at disproportionately high rates in some smaller, more rural counties.

We continue to see populations moving for various reasons, commonly pursuing higher education in younger aged individuals. ${ }^{15}$ Individuals who are moving from one place to the other may lack social support and consistent healthcare during and after the move. ${ }^{14}$ Public health professionals should consider developing interventions within vulnerable moving populations.

Based on these data, we suggest the following action steps. First, public health researchers should assess how population-level changes may be related to other communicable diseases in Missouri. Second, a yearly analysis should be conducted by the Missouri Department of Health and Senior Services to understand how population change may be impacting communicable diseases in Missouri and recommendations for clinical interventions should be developed and implemented by delving into the qualitative side of the data. Lastly, clinicians and public health practitioners in areas with growing, changing populations need to screen more patients for STIs, especially those who have recently moved. On the national level, a similar analysis should be conducted to evaluate the effects of population growth, among other variables, on the nation's STI rates.

The data for this study does not allow assessment of immigration or emigration or differences due to births/deaths, showing a limitation. Population change is a complex variable. Individuals are likely 
moving within the state. Additionally, rural counties could be losing population due to fewer births. These population-level data do not measure within state population change. In the future, this assessment should be conducting at the national level, while also accounting for and quantifying immigration and emigration within overall population change. This is a population-level study and results are generalizable only to the state of Missouri. The two most populous areas border other states: St Louis bordering Illinois and Kansas City bordering Kansas, making it a unique environment to study. Additionally, there may be other external variables that influence the relationships that were not accounted for in the methodology. This further shows the need for this analysis to be produced at the national level.

This study uses multiple data sets from the state of Missouri. By integrating many datasets, we are able to study how changing populations may impact health outcomes. This allows for a socioeconomic understanding of health outcomes. If healthcare and public health professionals can quantify how populations will increase and change with population change, precision public health can create targeted interventions. This may take place through evaluation and integration of this study or similar studies into Community Health Improvement Plans (CHIPs) which then develops to include intervention plans based off the findings.

This work follows the social epidemiology network, focused around the social capital subset and some neighborhood effects. Direct neighborhood effects from social isolation of a moving population may explain increasing rates of STIs in growing communities with social ties disrupted. Indirect neighborhood effects of increased unemployment may explain the further movement of populations in search of work, with STIs spreading alongside. More research should be done on these possible implications for social theory. Authors of this manuscript plan to conduct further analyzes using additional covariate data to test the relationships among social capital, neighbor effects, and communicable disease. More interventions and research must also be conducted on policies, Community Health Improvement Plans (CHIPs), laws, and economic factors involved in potential prevention methods for STIs. Population-wide plans should be developed and implemented to benefit the community and reduce the health and economic burden of STIs. STIs continue to pose a growing problem across the United States, Midwest region, and the state of Missouri. Prevention and response are of utmost importance as HIV continues to spread and multi-drug resistance in gonorrhea becomes more apparent in the population. Population-level predictors are imperative to understanding STI rate changes and predicting when they may occur so that intervention may be put into place. As populations change in Missouri, due to movement, unemployment rates, or other variables, STIs change with them. Health care and public health providers should respond to moving populations and individuals through screening for STIs and implementing preventative measures. Missouri law and policy makers should develop legislation to better support moving populations and those facing unemployment in order to limit the spread of STIs. Further, legislation should be drafted to prevent unemployment rates from increasing and making preventative measures, like condoms and sexual education, more widespread. This way, the health and wealth of Missourians and United States residents may be bettered. 


\section{Declarations}

Ethics Approval: This study was approved through the University of Missouri -Kansas City under IRB project number 2015743.

Consent: The author's give them manuscript consent to be published. There was not needed consent from other individuals throughout this process.

Availability of data and materials: The datasets generated or analyzed during this study are available from the corresponding author on reasonable request.

Competing Interests: The authors declare that they have no competing interests.

Funding: The was no funding utilized in this study.

Authors contributions: EV analyzed linear regressions and was a major contributor in writing the manuscript. JL was a major contributor in writing the manuscript. AR was a major contributor to running and analyzing the AIC statistics.

Acknowledgement: The authors would like to acknowledge Mark Gray and the University of Missouri Kansas City faculty and staff.

\section{References}

1. Centers for Disease Control and Prevention [internet]. Atlanta: The Centers c2018 [cited 2018 July 24]. 2017 Sexually Transmitted Diseases Surveillance - Chlamydia; [about 2 screens]. Available from https://www.cdc.gov/std/stats17/chlamydia.htm.

2. Centers for Disease Control and Prevention [internet]. Atlanta: The Centers c2018 [cited 2018 July 24]. 2017 Sexually Transmitted Diseases Surveillance -Gonorrhea; [about 2 screens]. Available from https://www.cdc.gov/std/stats17/Gonorrhea.htm

3. Centers for Disease Control and Prevention [internet]. Atlanta: The Centers c2018 [cited 2020 April 6]. 2017 Sexually Transmitted Diseases Surveillance- Syphilis Available from https://www.cdc.gov/std/stats17/syphilis.htm

4. US Department of Health and Human Services [internet]. Washington D.C. HIV.gov c2020 [cited 2020 June 30] U.S. Statistics [about 3 screens]. Available from https://www.hiv.gov/hivbasics/overview/data-and-trends/statistics

5. Lane SD, Rubinstein RA, Keefe RH, Webster N, Cibula D, Rosenthal A, et al. Structural Violence and Racial Disparity in HIV Transmission. Journal of Health Care for the Poor and Underserved. 2004 Aug 15;15(3):319-335. PMID: 15453172.

6. Ahuja N, Schmidt M, Dillon PJ, Alexander A, Kedia S. Online Narratives of Methamphetamine Use and Risky Sexual Behavior: Can Shame-Free Guilt Aid in Recovery? Archives of Sexual Behavior. 2020. 
7. Cwikel J. Social Epidemiology: Strategies for Public Health Activism. New York, NY: Columbia University Press; 2006.

8. Healthy People 2020 [internet]. Washington D.C.: Sexually Transmitted Diseases; c2020 [cited 2020 April 17]. Sexually Transmitted Diseases; [about 4 screens]. Available from https://www.healthypeople.gov/2020/topics-objectives/topic/sexually-transmitted-diseases

9. Owusu-Edusei K, Chesson HW, Gift TL, Tao G, Mahajan R Ocfemia M et al. The Estimated Direct Medical Cost of Selected Sexually Transmitted Infections in the United States, 2008. Sexually Transmitted Diseases. 2013;40(3):197-201.

10. Alirol E, Wi TE, Bala M, Bazzo M, Chen X, Deal $C$ et al. Multidrug-resistant gonorrhea: A research and development roadmap to discover new medicines. PLOS Medicine. 2017;14(7).

11. Centers for Disease Control and Prevention [internet]. Atlanta: The Center; c 2020 [cited 2020 October 10]. Missouri - State Health Profile. [about 4 screens]. Available from https://www.cdc.gov/nchhstp/stateprofiles/pdf/missouri_profile.pdf

12. Wu J, Jenerette GD, Buyantuyev A, Redman C. Quantifying spatiotemporal patterns of urbanization: The case of the two fastest growing metropolitan regions in the United States. Ecological Complexity. 2011;8(1):1-8.

13. Davis MJ. The Effects of Unemployment and Poverty on Sexual Appetite and Sexual Risk in Emerging and Young Adults. Sexual Addiction \& Compulsivity. 2009;16(4):267-288.

14. Poundstone, K. E., Strathdee, S. A., \& Celentano, D. D. (2004). The Social Epidemiology of Human Immunodeficiency Virus/Acquired Immunodeficiency Syndrome. Epidemiologic Reviews, 26(1).

15. Norris AH, Loewenberg Weisband $Y$, Wiles $M$, et al. Prevalence of sexually transmitted infections among Tanzanian migrants: a cross-sectional study. International Journal of STD and AIDS. 2017;28(10).

16. Riemer JW. Job relocation, sources of stress, and sense of home. Community, Work \& Family. 2000;3(2):205-217. doi:10.1080/713658901.

17. Open Database: Population MICA [internet]. Jefferson City (MO): Missouri Department of Health and Senior Services. c2020 - [cited 2020 June 10]. Available from https://healthapps.dhss.mo.gov/MoPhims/QueryBuilder?qbc=PNM\&q=1\&m=1

18. Open Database: Data \& Statistical Reports [internet]. Jefferson City (MO): Missouri Department of Health and Senior Services. c2020 - [cited 2019 June 19]. Available from https://health.mo.gov/data/hivstdaids/data.php

19. Open Database: AtlasPlus [internet] Atlanta (GA): The Centers for Disease Control and Prevention c 2018 - [cited 2019 June 20]. Available from: https://gis.cdc.gov/grasp/nchhstpatlas/tables.html

20. US Census [internet]. Washington D.C.: The Organization; c2019 [cited 2019 June 20]. Small Area Income and Poverty Estimates (SAIPE). Available from https://www.census.gov/datatools/demo/saipe/

21. van Wees, DA, Heijne, J, Basten, $M$ et al. Longitudinal Patterns of Sexually Transmitted Infection Risk Based on Psychological Characteristics and Sexual Behavior in Heterosexual Sexually Transmitted 
Infection Clinic Visitors, Sexually Transmitted Diseases. 2020 Mar;47 (3):171-5.

22. Wagenmakers E-J, Farrell S. AIC model selection using Akaike weights. Psychonomic Bulletin \& Review. 2004;11(1):192-196.

\section{Tables}


Table 1

Sample Characteristics by County (change from 2008-2017) -To appear between line 181 and 182

\begin{tabular}{|c|c|c|c|c|c|c|}
\hline Counties & $\begin{array}{l}\% \\
\text { Change } \\
\text { White }\end{array}$ & $\begin{array}{l}\% \text { Change } \\
\text { African } \\
\text { American }\end{array}$ & $\begin{array}{l}\% \\
\text { Change } \\
\text { Latinx }\end{array}$ & $\begin{array}{l}\text { \% Change } \\
\text { Avg. Yearly } \\
\text { Income }\end{array}$ & $\begin{array}{l}\text { \% Change Avg. } \\
\text { Unemployment } \\
\text { Rate }\end{array}$ & $\begin{array}{l}\text { \% Change in } \\
\text { Population } \\
\text { Size }\end{array}$ \\
\hline Adair & -3.21 & 89.34 & 21.70 & 10.8 & $-18,87$ & -0.09 \\
\hline Andrew & -1.60 & 80.01 & 56.21 & 13.24 & -33.33 & -9.02 \\
\hline Atchison & -1.10 & 0.08 & 41.89 & 10.2 & -27.08 & -9.02 \\
\hline Audrain & -1.74 & 7.82 & 34.42 & 8.07 & -43.55 & -0.52 \\
\hline Barry & -4.01 & 93.42 & 26.09 & 6.71 & -40 & -0.69 \\
\hline Barton & -2.55 & 104.77 & 66.03 & 12 & -54.84 & -5.87 \\
\hline Bates & -1.58 & 53.44 & 46.90 & 11.7 & -37.5 & -5 \\
\hline Benton & -1.40 & 69.16 & 51.88 & 3.1 & -26.09 & 0.15 \\
\hline Bollinger & -1.10 & 116.78 & 60.17 & 14.3 & -34.33 & -0.99 \\
\hline Boone & -2.95 & 5.39 & 18.35 & 10.18 & -40.91 & 12.77 \\
\hline Buchanan & -4.70 & 18.70 & 42.98 & 9.59 & -30.77 & 0.85 \\
\hline Butler & -1.52 & 10.33 & 31.23 & 6.38 & -27.42 & 0.74 \\
\hline Caldwell & -1.63 & 66.94 & 54.27 & -2.38 & -38.81 & -2.77 \\
\hline Callaway & -0.61 & -3.37 & 27.19 & 6.01 & -35.19 & 2.68 \\
\hline Camden & -1.53 & 44.60 & 35.89 & 11.91 & -23.81 & 4.99 \\
\hline $\begin{array}{l}\text { Cape } \\
\text { Girardeau }\end{array}$ & -2.59 & 18.66 & 23.53 & 6.29 & -32.69 & 5.42 \\
\hline Carroll & -1.02 & 23.39 & 29.87 & 6.57 & -43.66 & -6.93 \\
\hline Carter & -1.58 & 191.51 & 58.78 & 9.17 & -19.44 & 0.77 \\
\hline Cass & -1.98 & 19.88 & 18.13 & 10.98 & -41.67 & 5.74 \\
\hline Cedar & -1.48 & 159.69 & 52.51 & 8.57 & -36.92 & -0.33 \\
\hline Chariton & -1.22 & 16.11 & 109.33 & 5.53 & -43.55 & -4.46 \\
\hline Christian & -0.97 & 29.63 & 19.57 & 8.82 & -38 & 14.36 \\
\hline Clark & -0.85 & 58.21 & 78.59 & 5.32 & -8.2 & -6.21 \\
\hline Clay & -4.20 & 34.85 & 22.86 & 3.99 & -30.77 & 12.89 \\
\hline
\end{tabular}




\begin{tabular}{|c|c|c|c|c|c|c|}
\hline Counties & $\begin{array}{l}\% \\
\text { Change } \\
\text { White }\end{array}$ & $\begin{array}{l}\text { \% Change } \\
\text { African } \\
\text { American }\end{array}$ & $\begin{array}{l}\% \\
\text { Change } \\
\text { Latinx }\end{array}$ & $\begin{array}{l}\text { \% Change } \\
\text { Avg. Yearly } \\
\text { Income }\end{array}$ & $\begin{array}{l}\text { \% Change Avg. } \\
\text { Unemployment } \\
\text { Rate }\end{array}$ & $\begin{array}{l}\text { \% Change in } \\
\text { Population } \\
\text { Size }\end{array}$ \\
\hline Clinton & -0.88 & 12.20 & 34.50 & 9.44 & -32.2 & -1.09 \\
\hline \multicolumn{7}{|l|}{ Cole } \\
\hline Cooper & -1.16 & -2.25 & 60.62 & 0.55 & -36.84 & 0.81 \\
\hline Crawford & -1.16 & 69.26 & 38.14 & 27.88 & -43.21 & -2.41 \\
\hline Dade & -1.30 & 35.45 & 50.63 & 14.26 & -46.03 & -4.57 \\
\hline Dallas & -0.92 & 86.15 & 32.28 & 7.55 & -38.16 & -1.66 \\
\hline Daviess & -1.50 & 106.55 & 64.45 & 9.66 & -38.89 & 0.37 \\
\hline Dekalb & -2.22 & 8.09 & 55.89 & 22.08 & -38.1 & -1.91 \\
\hline Dent & -1.95 & 49.06 & 102.4 & 5.95 & -45.45 & -0.1 \\
\hline Douglas & -1.74 & 140.53 & 115.58 & 9.1 & -32.35 & -3.62 \\
\hline Dunklin & -3.33 & 7.76 & 31.99 & 4.86 & -17.72 & -6.34 \\
\hline Franklin & -0.96 & 16.84 & 36.49 & 6.43 & -52 & 2.16 \\
\hline Gasconade & -1.21 & 157.73 & 50.49 & 3.58 & -50 & -3.81 \\
\hline Gentry & -2.16 & 129.76 & 244.28 & 23.52 & -37.78 & -2.07 \\
\hline Greene & -2.43 & 21.92 & 32.06 & 9.31 & -39.22 & 6.98 \\
\hline Grundy & -1.74 & 90.99 & 34.78 & 8.4 & -35.71 & -2.42 \\
\hline Harrison & -1.53 & 85.70 & 50.10 & 15.25 & -28.57 & -4.82 \\
\hline Henry & -1.91 & 40.65 & 62.03 & -5.31 & -38.81 & -2.57 \\
\hline Hickory & -1.71 & 130.59 & 95.32 & 10.27 & -53.61 & -1.22 \\
\hline Holt & -1.20 & 169.76 & 66.01 & 15.24 & -42 & -10.41 \\
\hline Howard & -0.62 & -2.74 & 32.76 & 7.93 & -36.67 & 0.01 \\
\hline Howell & -0.84 & 40.06 & 20.47 & 6.11 & -17.54 & 0.48 \\
\hline Iron & -1.49 & 40.96 & 57.31 & -10.68 & 12.28 & -4.13 \\
\hline Jackson & -2.29 & -0.82 & 17.18 & 7.94 & -36.23 & 5.03 \\
\hline Jasper & -3.02 & 20.60 & 26.42 & 8.62 & -34.62 & 4.41 \\
\hline Jefferson & -1.03 & 28.21 & 31.65 & 10.64 & -47.83 & 3.42 \\
\hline
\end{tabular}




\begin{tabular}{|c|c|c|c|c|c|c|}
\hline Counties & $\begin{array}{l}\% \\
\text { Change } \\
\text { White }\end{array}$ & $\begin{array}{l}\text { \% Change } \\
\text { African } \\
\text { American }\end{array}$ & $\begin{array}{l}\% \\
\text { Change } \\
\text { Latinx }\end{array}$ & $\begin{array}{l}\% \text { Change } \\
\text { Avg. Yearly } \\
\text { Income }\end{array}$ & $\begin{array}{l}\text { \% Change Avg. } \\
\text { Unemployment } \\
\text { Rate }\end{array}$ & $\begin{array}{l}\% \text { Change in } \\
\text { Population } \\
\text { Size }\end{array}$ \\
\hline Johnson & -3.13 & 21.36 & 50.26 & 2.45 & -16.98 & 3.87 \\
\hline Knox & -0.78 & 71.03 & 18.74 & 5.3 & -31.91 & -3.4 \\
\hline Laclede & -1.27 & 32.93 & 29.31 & 8.35 & -36.84 & -0.21 \\
\hline Lafayette & -1.08 & -0.62 & 37.07 & 7.99 & -37.7 & -2.37 \\
\hline Lawrence & -2.43 & 82.82 & 27.15 & 12.05 & -27.08 & -0.19 \\
\hline Lewis & -1.12 & 9.23 & 29.29 & 12.89 & -29.17 & -2.25 \\
\hline Lincoln & -0.95 & 3.78 & 28.27 & 15.1 & -53.85 & 8.36 \\
\hline Linn & -1.57 & 35.58 & 68.96 & 5.1 & -17.14 & -4.64 \\
\hline Livingston & -2.83 & 49.61 & 78.04 & 4.05 & -44.23 & 1.63 \\
\hline Macon & -1.02 & 9.94 & 62.32 & 4.11 & -40 & -1.68 \\
\hline Madison & -1.69 & 112.43 & 31.76 & -1.15 & -26.23 & -1.23 \\
\hline Maries & -2.00 & 179.07 & 51.39 & 17.33 & -31.75 & -3.53 \\
\hline Marion & -0.86 & 1.49 & 30.70 & 29.28 & -35.71 & 0.29 \\
\hline Mcdonald & -4.87 & 260.75 & 9.16 & 4.49 & -24.49 & -0.5 \\
\hline Mercer & -2.59 & 103.81 & 249.38 & 8.53 & -22.92 & -1.87 \\
\hline Miller & -1.21 & 62.08 & 37.66 & 4.34 & -34.33 & 1.45 \\
\hline Mississippi & -2.82 & 5.15 & 44.39 & 8.11 & -31.51 & -3.56 \\
\hline Moniteau & -1.25 & 8.12 & 21.19 & 16.2 & -34.55 & 4.14 \\
\hline Monroe & -1.26 & 0.70 & 99.53 & 0.92 & -38.57 & -5.95 \\
\hline Montgomery & -1.25 & 8.18 & 49.43 & 14.47 & -54.17 & -6.8 \\
\hline Morgan & -1.53 & 53.82 & 45.99 & 15.3 & -34.67 & -2.89 \\
\hline New Madrid & -1.51 & 1.66 & 83.57 & -12.98 & -7.04 & -6.5 \\
\hline Newton & -2.54 & 41.36 & 36.54 & -20.74 & -34.55 & 1.2 \\
\hline Nodaway & -1.57 & 31.69 & 39.21 & 9.89 & -14.29 & -2.41 \\
\hline Oregon & -1.55 & 235.12 & 60.15 & 11.61 & -22.03 & -1.3 \\
\hline Osage & -0.85 & 92.58 & 61.32 & 14.08 & -51.61 & -0.66 \\
\hline
\end{tabular}




\begin{tabular}{|c|c|c|c|c|c|c|}
\hline Counties & $\begin{array}{l}\% \\
\text { Change } \\
\text { White }\end{array}$ & $\begin{array}{l}\text { \% Change } \\
\text { African } \\
\text { American }\end{array}$ & $\begin{array}{l}\% \\
\text { Change } \\
\text { Latinx }\end{array}$ & $\begin{array}{l}\text { \% Change } \\
\text { Avg. Yearly } \\
\text { Income }\end{array}$ & $\begin{array}{l}\text { \% Change Avg. } \\
\text { Unemployment } \\
\text { Rate }\end{array}$ & $\begin{array}{l}\text { \% Change in } \\
\text { Population } \\
\text { Size }\end{array}$ \\
\hline Ozark & -1.20 & 131.17 & 36.75 & 11.94 & -4.92 & -5.47 \\
\hline Pemiscot & -1.34 & -0.43 & 41.30 & -3.91 & 0 & -9.3 \\
\hline Perry & -1.48 & 77.46 & 50.67 & 11.04 & -41.3 & 1.31 \\
\hline Pettis & -3.29 & 7.52 & 33.20 & 7.49 & -32.26 & 2.39 \\
\hline Phelps & -2.26 & 16.43 & 30.18 & 8.72 & -37.29 & 1.23 \\
\hline Pike & -0.65 & 1.03 & 19.94 & 5.4 & -40.35 & -0.19 \\
\hline Platte & -4.82 & 31.10 & 32.69 & 5.12 & -33.33 & 16.3 \\
\hline Polk & -1.81 & 41.12 & 40.61 & 5.94 & -34.43 & 3.26 \\
\hline Pulaski & -5.05 & 2.54 & 31.63 & 7.89 & -24.56 & 7.78 \\
\hline Putnam & -2.04 & 129.92 & 175.79 & 4.29 & -29.63 & -4.32 \\
\hline Ralls & -1.25 & 59.85 & 43.54 & 6.76 & -41.51 & 1.06 \\
\hline Randolph & -1.15 & 0.79 & 32.98 & 5.66 & -26.23 & -2.55 \\
\hline Ray & -1.36 & 26.46 & 47.03 & 7.24 & -25 & -3.83 \\
\hline Reynolds & -1.98 & 98.20 & 63.20 & 44.4 & -46.58 & -6.18 \\
\hline Ripley & -1.05 & 123.06 & 44.36 & 4.41 & -17.91 & -3.38 \\
\hline Saline & -3.71 & 0.18 & 31.57 & 11.01 & -36.84 & -1.34 \\
\hline Schuyler & -1.31 & 94.45 & 130.10 & 3.54 & -25 & 2.85 \\
\hline Scotland & -0.84 & 129.46 & 62.84 & 9.97 & -53.03 & 3.01 \\
\hline Scott & -1.53 & 4.42 & 35.01 & 11.54 & -33.33 & -1.91 \\
\hline Shannon & -1.19 & 180.70 & 21.55 & 19.79 & -22.78 & -2.03 \\
\hline Shelby & -2.17 & 109.02 & 100.74 & 7.19 & -35.85 & -6.23 \\
\hline St Charles & -1.81 & 25.83 & 27.94 & 6.42 & -47.27 & 11.67 \\
\hline St Clair & -1.50 & 37.45 & 48.24 & 8.9 & -28.17 & -4.05 \\
\hline St Francois & -1.24 & 13.14 & 41.96 & 6.58 & -38.03 & 3.77 \\
\hline St Louis & 2.25 & -9.72 & 21.25 & 5.94 & -43.33 & -0.16 \\
\hline St louis City & -2.37 & 11.21 & 29.47 & 4.68 & -43.59 & -2.93 \\
\hline
\end{tabular}




\begin{tabular}{|lllllll|}
\hline Counties & $\begin{array}{l}\text { \% } \\
\text { Change } \\
\text { White }\end{array}$ & $\begin{array}{l}\text { \% Change } \\
\text { African } \\
\text { American }\end{array}$ & $\begin{array}{l}\text { \% } \\
\text { Change } \\
\text { Latinx }\end{array}$ & $\begin{array}{l}\text { \% Change } \\
\text { Avg. Yearly } \\
\text { Income }\end{array}$ & $\begin{array}{l}\text { \% Change Avg. } \\
\text { Unemployment } \\
\text { Rate }\end{array}$ & $\begin{array}{l}\text { \% Change in } \\
\text { Population } \\
\text { Size }\end{array}$ \\
\hline $\begin{array}{l}\text { Ste } \\
\text { Genevieve }\end{array}$ & -1.86 & 31.49 & 65.62 & 4.74 & -38.98 & -1.89 \\
\hline Stoddard & -1.22 & 26.12 & 65.82 & 12.41 & -33.33 & -2.31 \\
\hline Stone & -1.57 & 161.85 & 42.27 & 15.19 & -29.49 & -1.31 \\
\hline Sullivan & -5.19 & 470.74 & 8.910 & 23.09 & -31.03 & -7.53 \\
\hline Taney & -3.06 & 86.00 & 33.18 & 7.95 & -22.08 & 11.35 \\
\hline Texas & -1.46 & 16.49 & 34.97 & 6.65 & -28.99 & 0.54 \\
\hline Vernon & -1.40 & 79.97 & 39.81 & 8.21 & -32.14 & -2.17 \\
\hline Warren & -1.20 & 17.60 & 19.35 & 12.82 & -57.33 & 7.5 \\
\hline Washinton & -0.84 & 8.23 & 48.29 & 7.3 & -47.06 & -0.36 \\
\hline Wayne & -1.85 & 151.90 & 96.22 & 16.91 & -25 & -0.75 \\
\hline Webster & -0.99 & 27.22 & 30.13 & 6.96 & -31.58 & 7.59 \\
\hline Worth & & & & & & \\
\hline
\end{tabular}


Table 2

Percent Change in STIs from 2008 to 2017 while controlling for Population Change - To appear between lines 186 and 187

\begin{tabular}{|c|c|c|c|c|c|}
\hline & $\begin{array}{l}\text { \% Change } \\
\text { Chlamydia } \\
\text { incidence }\end{array}$ & $\begin{array}{l}\text { \% Change } \\
\text { Gonorrhea } \\
\text { incidence }\end{array}$ & $\begin{array}{l}\text { \% Change } \\
\text { Syphilis } \\
\text { Incidence }\end{array}$ & $\begin{array}{l}\text { \% Change } \\
\text { HIV } \\
\text { diagnoses }\end{array}$ & $\begin{array}{l}\text { \% Change } \\
\text { HIV } \\
\text { Prevalence }\end{array}$ \\
\hline Adair & 50.13 & 57.28 & 0 & 282.42 & 0 \\
\hline Andrew & 28.54 & 864.06 & **NA 0-1 & 0 & 0 \\
\hline Atchison & 449.57 & **NA 0-1 & 0 & 0 & 0 \\
\hline Audrain & 76.70 & 101.04 & 804.67 & -0.95 & 0 \\
\hline Barry & 97.67 & 156.47 & 0 & 302.27 & 0 \\
\hline Barton & 123.10 & 0 & 0 & 0 & 0 \\
\hline Bates & 100.50 & 1794.77 & 0 & 121.10 & 0 \\
\hline Benton & 103.70 & 249.49 & 0 & 266.48 & 0 \\
\hline Bollinger & 44.49 & 236.67 & 0 & 0 & 0 \\
\hline Boone & 41.38 & 10.40 & 18.24 & -4.05 & -18.62 \\
\hline Buchanan & 57.41 & 663.53 & 280.11 & 6.45 & 0 \\
\hline Butler & 54.22 & 236.89 & -66.91 & 88.75 & 0 \\
\hline Caldwell & 14.95 & 259.96 & 0 & 0 & 0 \\
\hline Callaway & 57.90 & 75.30 & 581.70 & -45.52 & 0 \\
\hline Camden & 185.73 & 1042.93 & 0 & 339.53 & 0 \\
\hline $\begin{array}{l}\text { Cape } \\
\text { Girardeau }\end{array}$ & 18.43 & -0.83 & 208.28 & 29.93 & 0 \\
\hline Carroll & 25.35 & 544.68 & 0 & 0 & 0 \\
\hline Carter & 1190.10 & 0 & 0 & 0 & 0 \\
\hline Cass & 58.05 & 312.44 & 104.91 & 88.49 & 0 \\
\hline Cedar & 16.39 & 451.84 & 0 & -100.00 & 0 \\
\hline Chariton & 33.74 & 4.67 & 0 & 0 & 0 \\
\hline
\end{tabular}

**NA indicates a change from 0 to 1 case from 2008-2017

*HIV Prevalence and Diagnoses take values from 2008-2016 


\begin{tabular}{|c|c|c|c|c|c|}
\hline & $\begin{array}{l}\text { \% Change } \\
\text { Chlamydia } \\
\text { incidence }\end{array}$ & $\begin{array}{l}\text { \% Change } \\
\text { Gonorrhea } \\
\text { incidence }\end{array}$ & $\begin{array}{l}\text { \% Change } \\
\text { Syphilis } \\
\text { Incidence }\end{array}$ & $\begin{array}{l}\text { \% Change } \\
\text { HIV } \\
\text { diagnoses }\end{array}$ & $\begin{array}{l}\text { \% Change } \\
\text { HIV } \\
\text { Prevalence }\end{array}$ \\
\hline Christian & 117.77 & 158.83 & 45.74 & 90.43 & 0 \\
\hline Clark & 113.24 & 0 & 0 & 0 & 0 \\
\hline Clay & 36.02 & 144.18 & 172.07 & 60.62 & 22.71 \\
\hline Clinton & 55.99 & 183.09 & -100.00 & 10.91 & 0 \\
\hline \multicolumn{6}{|l|}{ Cole } \\
\hline Cooper & 7.82 & 296.78 & 0 & 136.06 & -100.00 \\
\hline Crawford & 75.20 & 2154.40 & 0 & 286.19 & 0 \\
\hline Dade & 49.69 & 57.18 & 0 & 0 & 0 \\
\hline Dallas & 138.97 & 476.25 & 0 & 0 & 0 \\
\hline Daviess & 124.17 & 697.03 & 0 & 0 & 0 \\
\hline Dekalb & -3.40 & 205.84 & 1.95 & -66.09 & 0 \\
\hline Dent & 27.90 & 500.58 & 0 & 0 & 0 \\
\hline Douglas & 250.19 & 366.92 & 0 & 0 & 0 \\
\hline Dunklin & 32.47 & 144.79 & 967.70 & -6.39 & 0 \\
\hline Franklin & 85.15 & 401.68 & -75.53 & 34.49 & 0 \\
\hline Gasconade & 107.92 & 419.79 & 0 & -26.15 & 0 \\
\hline Gentry & 147.99 & 512.69 & 0 & 0 & 0 \\
\hline Greene & 152.78 & 320.65 & 72.35 & 12.48 & -65.25 \\
\hline Grundy & 19.01 & 130.59 & 0 & 0 & 0 \\
\hline Harrison & 202.07 & 740.54 & -100.00 & 0 & 0 \\
\hline Henry & 96.72 & 146.33 & 207.92 & 85.81 & 0 \\
\hline Hickory & 120.88 & 304.94 & 0 & 0 & 0 \\
\hline Holt & -16.28 & 123.25 & 0 & 0 & 0 \\
\hline Howard & 11.10 & -33.34 & 0 & -100.00 & 0 \\
\hline
\end{tabular}

**NA indicates a change from 0 to 1 case from 2008-2017

*HIV Prevalence and Diagnoses take values from 2008-2016 


\begin{tabular}{|c|c|c|c|c|c|}
\hline & $\begin{array}{l}\text { \% Change } \\
\text { Chlamydia } \\
\text { incidence }\end{array}$ & $\begin{array}{l}\text { \% Change } \\
\text { Gonorrhea } \\
\text { incidence }\end{array}$ & $\begin{array}{l}\text { \% Change } \\
\text { Syphilis } \\
\text { Incidence }\end{array}$ & $\begin{array}{l}\text { \% Change } \\
\text { HIV } \\
\text { diagnoses }\end{array}$ & $\begin{array}{l}\text { \% Change } \\
\text { HIV } \\
\text { Prevalence }\end{array}$ \\
\hline Howell & 84.04 & 397.59 & 491.11 & -36.84 & 0 \\
\hline Iron & 47.78 & 108.63 & 0 & 0 & 0 \\
\hline Jackson & 0.15 & 27.73 & 122.64 & -0.02 & -22.80 \\
\hline Jasper & 51.56 & 167.66 & 115.51 & 47.69 & -100.00 \\
\hline Jefferson & 138.32 & 246.30 & 866.93 & 53.71 & 0 \\
\hline Johnson & 36.83 & 152.15 & 0 & 54.60 & 0 \\
\hline Knox & 3.52 & -65.49 & 0 & 0 & 0 \\
\hline Laclede & 23.12 & 483.05 & 0 & 38.57 & 0 \\
\hline Lafayette & 48.84 & 651.15 & 207.29 & -25.97 & 0 \\
\hline Lawrence & 134.93 & 213.10 & 0.19 & 33.77 & 0 \\
\hline Lewis & -28.70 & 53.45 & 0 & 0 & 0 \\
\hline Lincoln & 100.35 & 161.47 & -53.86 & 134.53 & 0 \\
\hline Linn & -28.70 & -100.00 & 0 & -100.00 & 0 \\
\hline Livingston & 104.35 & 96.78 & 0 & 0 & 0 \\
\hline Macon & 1.71 & -43.49 & 0 & 0 & 0 \\
\hline Madison & 1.25 & 102.50 & 0 & -0.38 & 0 \\
\hline Maries & 3.65 & 0 & 0 & 0 & 0 \\
\hline Marion & 35.25 & 3.86 & 0 & 122.32 & 0 \\
\hline Mcdonald & 69.14 & 1055.79 & 0 & 88.37 & 0 \\
\hline Mercer & 1.90 & 0 & 0 & 0 & 0 \\
\hline Miller & 73.79 & 220.35 & 0 & -31.70 & 0 \\
\hline Mississippi & -29.55 & 3.69 & 0 & 72.49 & 0 \\
\hline Moniteau & 63.24 & 284.09 & -3.98 & 71.19 & 0 \\
\hline Monroe & 6.33 & -57.47 & 0 & 0 & 0 \\
\hline
\end{tabular}

**NA indicates a change from 0 to 1 case from 2008-2017

*HIV Prevalence and Diagnoses take values from 2008-2016 


\begin{tabular}{|c|c|c|c|c|c|}
\hline & $\begin{array}{l}\text { \% Change } \\
\text { Chlamydia } \\
\text { incidence }\end{array}$ & $\begin{array}{l}\text { \% Change } \\
\text { Gonorrhea } \\
\text { incidence }\end{array}$ & $\begin{array}{l}\text { \% Change } \\
\text { Syphilis } \\
\text { Incidence }\end{array}$ & $\begin{array}{l}\text { \% Change } \\
\text { HIV } \\
\text { diagnoses }\end{array}$ & $\begin{array}{l}\text { \% Change } \\
\text { HIV } \\
\text { Prevalence }\end{array}$ \\
\hline Montgomery & 177.19 & 758.40 & 0 & -33.99 & 0 \\
\hline Morgan & 116.80 & 346.24 & 0 & -100.00 & 0 \\
\hline New Madrid & 66.38 & 203.98 & 0 & 43.14 & 0 \\
\hline Newton & 103.45 & 114.10 & 295.27 & -67.29 & 0 \\
\hline Nodaway & 46.20 & 432.82 & -100.00 & 6.89 & 0 \\
\hline Oregon & 406.58 & 0 & 0 & -100.00 & 0 \\
\hline Osage & 111.40 & 101.33 & 0 & 0 & 0 \\
\hline Ozark & 196.22 & *NA & 0 & -100.00 & 0 \\
\hline Pemiscot & 16.99 & 6.39 & 120.52 & 13.39 & 0 \\
\hline Perry & 73.72 & 12.81 & 0 & 0 & 0 \\
\hline Pettis & 35.83 & -39.54 & 0 & -6.22 & 0 \\
\hline Phelps & 28.81 & 97.57 & 97.57 & $-24 / 23$ & 0 \\
\hline Pike & 24.56 & 12.71 & 0 & 0.89 & 0 \\
\hline Platte & 26.80 & 79.64 & 11.78 & 7.83 & 59.30 \\
\hline Polk & 184.60 & 74.32 & 0 & 313.35 & 0 \\
\hline Pulaski & 8.70 & 10.04 & -53.61 & 41.12 & 0 \\
\hline Putnam & -37.29 & 0 & 0 & 0 & 0 \\
\hline Ralls & 54.61 & 295.81 & 0 & 0 & 0 \\
\hline Randolph & 3.71 & -36.48 & 0 & -23.18 & 0 \\
\hline Ray & 39.37 & 232.73 & 0 & -21.67 & 0 \\
\hline Reynolds & 166.45 & 6.58 & 0 & 0 & 0 \\
\hline Ripley & 63.88 & 131.50 & 0 & 0 & 0 \\
\hline Saline & 25.82 & 102.71 & 1.35 & -8.39 & 0 \\
\hline Schuyler & 36.12 & 0 & 0 & 0 & 0 \\
\hline
\end{tabular}

**NA indicates a change from 0 to 1 case from 2008-2017

*HIV Prevalence and Diagnoses take values from 2008-2016 


\begin{tabular}{|c|c|c|c|c|c|}
\hline & $\begin{array}{l}\text { \% Change } \\
\text { Chlamydia } \\
\text { incidence }\end{array}$ & $\begin{array}{l}\text { \% Change } \\
\text { Gonorrhea } \\
\text { incidence }\end{array}$ & $\begin{array}{l}\text { \% Change } \\
\text { Syphilis } \\
\text { Incidence }\end{array}$ & $\begin{array}{l}\text { \% Change } \\
\text { HIV } \\
\text { diagnoses }\end{array}$ & $\begin{array}{l}\text { \% Change } \\
\text { HIV } \\
\text { Prevalence }\end{array}$ \\
\hline Scotland & -2.92 & 482.47 & 0 & 0 & 0 \\
\hline Scott & 14.06 & 0.72 & 0 & 1.41 & 0 \\
\hline Shannon & 155.18 & 0 & 0 & -100.00 & 0 \\
\hline Shelby & 35.73 & -100.00 & 0 & 0 & 0 \\
\hline St Charles & 57.64 & 173.75 & 85.07 & 61.18 & 44.96 \\
\hline St Clair & 11.66 & 160.55 & 0 & 0 & 0 \\
\hline St Francois & 143.99 & 413.94 & 317.58 & -34.98 & 941.96 \\
\hline St Louis & 20.13 & 50.47 & 187.70 & 39.95 & 20.97 \\
\hline St louis City & -3.47 & 19.37 & 128.56 & 4.42 & -100.00 \\
\hline $\begin{array}{l}\text { Ste } \\
\text { Genevieve }\end{array}$ & 246.54 & 103.84 & 0 & 0 & 0 \\
\hline Stoddard & 84.65 & 236.32 & 0 & 62.56 & 0 \\
\hline Stone & 142.05 & 125.17 & -49.34 & 164.38 & 0 \\
\hline Sullivan & 8.14 & 332.56 & 0 & 0 & 0 \\
\hline Taney & 73.75 & 544.96 & 34.71 & 10.46 & 0 \\
\hline Texas & 40.55 & 397.32 & 198.39 & -0.69 & 0 \\
\hline Vernon & 55.77 & 0 & 0 & -11.79 & 0 \\
\hline Warren & 19.83 & 86.05 & 0 & 104.96 & 0 \\
\hline Washington & 31.59 & 602.55 & 0.36 & 27.71 & 0 \\
\hline Wayne & 157.50 & 403.80 & 0 & 0 & 0 \\
\hline Webster & 97.05 & 160.25 & 85.89 & 27.32 & 0 \\
\hline \multicolumn{6}{|l|}{ orth } \\
\hline Wright & 72.99 & 776.57 & 0 & -26.16 & 0 \\
\hline \multicolumn{6}{|c|}{$\star \star N A$ indicates a change from 0 to 1 case from $2008-2017$} \\
\hline *HIV Prevalen & and Diagr & values $f$ & 3-2016 & & \\
\hline
\end{tabular}


Table 3

Associations among STIs and population change in Missouri. - To appear between lines 192 and 193 Chlamydia

\begin{tabular}{|c|c|c|c|c|c|}
\hline & $\begin{array}{l}\text { Standardized } \\
\text { Beta }\end{array}$ & $\begin{array}{l}\mathrm{t} \text { test } \\
\text { value }\end{array}$ & Significance & $\begin{array}{l}\text { B Confidence } \\
\text { Interval lower } \\
\text { limit }\end{array}$ & $\begin{array}{l}\text { B Confidence } \\
\text { Interval Upper } \\
\text { Limit }\end{array}$ \\
\hline $\begin{array}{l}\text { Population } \\
\text { Change 08-09 }\end{array}$ & 0.32 & 3.54 & 0.00 & 0.309 & 0.331 \\
\hline $\begin{array}{l}\text { Population } \\
\text { Change 09-10 }\end{array}$ & 0.03 & 0.30 & 0.77 & 0.018 & 0.312 \\
\hline $\begin{array}{l}\text { Population } \\
\text { change } 10-11\end{array}$ & 0.30 & 3.30 & 0.00 & 0.007 & 0.053 \\
\hline $\begin{array}{l}\text { Population } \\
\text { Change } 11-12\end{array}$ & 0.15 & 1.59 & 0.12 & 0.137 & 0.163 \\
\hline $\begin{array}{l}\text { Population } \\
\text { Change } 12-13\end{array}$ & -0.29 & -3.23 & 0.00 & -0.267 & -0.313 \\
\hline $\begin{array}{l}\text { Population } \\
\text { Change } 13-14\end{array}$ & 0.36 & 4.03 & 0.00 & 0.344 & 0.376 \\
\hline $\begin{array}{l}\text { Population } \\
\text { Change 14-15 }\end{array}$ & 0.59 & 7.69 & 0.00 & 0.567 & 0.613 \\
\hline $\begin{array}{l}\text { Population } \\
\text { Change } 15-16\end{array}$ & 0.32 & 3.52 & 0.00 & 0.144 & 0.496 \\
\hline $\begin{array}{l}\text { Population } \\
\text { Change } 16-17\end{array}$ & 0.21 & 2.29 & 0.02 & 0.201 & 0.219 \\
\hline $\begin{array}{l}\text { Population } \\
\text { Change 08-17 }\end{array}$ & 0.58 & 7.55 & 0.00 & 0.565 & 0.595 \\
\hline \multicolumn{6}{|l|}{ Gonorrhea } \\
\hline $\begin{array}{l}\text { Population } \\
\text { Change 08-09 }\end{array}$ & -0.19 & -2.08 & 0.04 & -0.207 & 0.173 \\
\hline $\begin{array}{l}\text { Population } \\
\text { Change 09-10 }\end{array}$ & 0.16 & 1.69 & 0.09 & 0.15 & 0.17 \\
\hline $\begin{array}{l}\text { Population } \\
\text { change } 10-11\end{array}$ & -0.05 & -0.50 & 0.62 & -0.054 & 0.046 \\
\hline $\begin{array}{l}\text { Population } \\
\text { Change } 11-12\end{array}$ & 0.16 & 1.71 & 0.09 & -0.155 & 0.165 \\
\hline $\begin{array}{l}\text { Population } \\
\text { Change } 12-13\end{array}$ & -0.28 & -3.07 & 0.00 & -0.271 & -0.28 \\
\hline
\end{tabular}




\section{Chlamydia}

$\begin{array}{llllll}\text { Population } & 0.03 & 0.33 & 0.74 & 0.029 & 0.031\end{array}$

Change 13-14

$\begin{array}{llllll}\text { Population } & 0.18 & 1.96 & 0.05 & 0.006 & 0.030\end{array}$

Change 14-15

\begin{tabular}{llllll}
$\begin{array}{l}\text { Population } \\
\text { Change 15-16 }\end{array}$ & -0.13 & -1.40 & 0.17 & -0.143 & -0.117 \\
\hline
\end{tabular}

\begin{tabular}{llllll}
$\begin{array}{l}\text { Population } \\
\text { Change 16-17 }\end{array}$ & 0.57 & 7.31 & 0.00 & 0.541 & 0.599 \\
\hline
\end{tabular}

\begin{tabular}{llllll}
$\begin{array}{l}\text { Population } \\
\text { Change 08-17 }\end{array}$ & 0.49 & 5.92 & 0.00 & 0.478 & 0.502 \\
\hline
\end{tabular}

Syphilis

\begin{tabular}{llllll}
$\begin{array}{l}\text { Population } \\
\text { Change 08-09 }\end{array}$ & -0.26 & -2.86 & 0.01 & -0.259 & -0.261 \\
$\begin{array}{l}\text { Population } \\
\text { Change 09-10 }\end{array}$ & -0.30 & -3.34 & 0.00 & -0.297 & -0.303 \\
$\begin{array}{l}\text { Population } \\
\text { change 10-11 }\end{array}$ & 0.10 & 1.10 & 0.27 & 0.099 & 0.101 \\
\hline $\begin{array}{l}\text { Population } \\
\text { Change 11-12 }\end{array}$ & 0.08 & 0.89 & 0.37 & 0.079 & 0.081 \\
$\begin{array}{l}\text { Population } \\
\text { Change 12-13 }\end{array}$ & 0.30 & 3.34 & 0.00 & 0.297 & 0.303 \\
$\begin{array}{l}\text { Population } \\
\text { Change 13-14 }\end{array}$ & 0.31 & 3.40 & 0.00 & 0.307 & 0.313 \\
\hline
\end{tabular}

$\begin{array}{llllll}\text { Population } & 0.10 & 1.10 & 0.27 & 0.099 & 0.101\end{array}$

\begin{tabular}{llllll}
$\begin{array}{l}\text { Population } \\
\text { Change 15-16 }\end{array}$ & -0.12 & 0.10 & 0.22 & -0.121 & -0.119 \\
\hline $\begin{array}{l}\text { Population } \\
\text { Change 16-17 }\end{array}$ & -0.12 & -1.33 & 0.19 & -0.121 & -0.119 \\
\hline $\begin{array}{l}\text { Population } \\
\text { Change 08-17 }\end{array}$ & 0.24 & 2.59 & 0.01 & 0.237 & 0.243
\end{tabular}

HIV Prevalence

\begin{tabular}{llllll}
$\begin{array}{l}\text { Population } \\
\text { Change 08-09 }\end{array}$ & 0.46 & 5.45 & 0.00 & 0.455 & 0.465 \\
\hline $\begin{array}{l}\text { Population } \\
\text { Change 09-10 }\end{array}$ & -0.25 & -2.75 & 0.01 & -0.286 & -0.214 \\
\hline
\end{tabular}




\section{Chlamydia}

Population

change 10-11

Population

0.17

$1.87 \quad 0.06$

0.161

0.179

Change 11-12

$\begin{array}{llllll}\begin{array}{l}\text { Population } \\ \text { Change 12-13 }\end{array} & 0.29 & 3.24 & 0.00 & 0.284 & 0.296\end{array}$

\section{Population}

0.12

$1.26 \quad 0.21$

0.118

0.123

Change 13-14

Population
Change 14-15

Population $\quad 0.03$

0.52

$6.47 \quad 0.00$

0.391

0.649

Change 15-16

$2.74 \quad 0.01$

0.000

0.006

HIV Diagnoses

Population

Change 08-09

$-0.40$

$-4.54 \quad 0.00$

$-0.405$

$-0.395$

Population

Change 09-10

0.12

1.24

0.22

0.119

0.121

Population

$-0.10$

$-1.00$

0.32

$-0.101$

0.000

change 10-11

Population

Change 11-12

$-0.03$

$-0.33$

0.75

$-0.353$

0.293

Population

$-0.13$

$-1.31 \quad 0.20$

$-0.133$

$-0.127$

Change 12-13

Population
Change 13-14

0.07

$0.78 \quad 0.44$

0.069

0.071

Population

0.06

$0.64 \quad 0.52$

0.059

0.061

Change 14-15

Population

0.30

3.26

0.00

0.297

0.303 
Table 4

Akaike Information Criterion Output - To appear between lines 194 and 195

\begin{tabular}{|c|c|c|c|c|c|}
\hline & Model & AIC & $\triangle \mathrm{AIC}$ & Wi* & $\mathrm{R}^{2}$ \\
\hline \multirow[t]{15}{*}{ Chlamydia } & $\begin{array}{l}\text { Population growth + unemployment }+ \\
\text { income }\end{array}$ & -135 & 0 & 0.2893 & 0.41 \\
\hline & Unemployment + income & -134.92 & 0.0887 & 0.2767 & 0.40 \\
\hline & $\begin{array}{l}\text { Population change }+ \text { unemployment }+ \\
\text { income }\end{array}$ & -133.912 & 0.0887 & 0.2768 & 0.41 \\
\hline & $\begin{array}{l}\text { Population growth }+ \text { population size }+ \\
\text { unemployment }+ \text { income }\end{array}$ & -133.10 & 1.9016 & 0.1118 & 0.42 \\
\hline & Income & -131.962 & 3.0279 & & \\
\hline & Population growth + income & -131.096 & 3.9044 & & \\
\hline & Population size + income & -130.773 & 4.2276 & & \\
\hline & $\begin{array}{l}\text { Population growth }+ \text { population size }+ \\
\text { income }\end{array}$ & -129.617 & 5.3828 & & \\
\hline & Population size & -105.627 & 29.3727 & & \\
\hline & Population growth + population size & -104.388 & 30.6119 & & \\
\hline & $\begin{array}{l}\text { Population growth }+ \text { population size }+ \\
\text { unemployment }\end{array}$ & -102.558 & 32.4423 & & \\
\hline & Population growth & -78.0372 & 56.9630 & & \\
\hline & Population growth + unemployment & -76.0378 & 58.9624 & & \\
\hline & Intercept of values & -75.4091 & 59.5911 & & \\
\hline & unemployment & -73.5686 & 61.4316 & & \\
\hline \multirow[t]{5}{*}{ Gonorrhea } & Population size + unemployment + income & -324.99 & 0 & 0.43552 & 0.41 \\
\hline & Unemployment + incomes & -324.096 & 0.8944 & 0.27848 & 0.38 \\
\hline & $\begin{array}{l}\text { Population growth }+ \text { population size }+ \\
\text { unemployment }+ \text { income }\end{array}$ & -323.004 & 1.9863 & 0.16132 & 0.41 \\
\hline & $\begin{array}{l}\text { Population growth + unemployment + } \\
\text { income }\end{array}$ & -322.153 & 2.8378 & & \\
\hline & Population size + income & -317.481 & 7.5093 & & \\
\hline \multicolumn{6}{|c|}{${ }^{*} \mathrm{~W}_{\mathrm{i}}$ and $\mathrm{R}^{2}$ were calculated for only those models considered to be of best fit } \\
\hline
\end{tabular}




\begin{tabular}{|c|c|c|c|c|c|}
\hline & Model & AIC & $\Delta$ AIC & Wi* & $\mathbf{R}^{2}$ \\
\hline & $\begin{array}{l}\text { Population growth }+ \text { population size }+ \\
\text { income }\end{array}$ & -315.911 & 9.0795 & & \\
\hline & Income & -315.172 & 9.8185 & & \\
\hline & Population growth + income & -313.239 & 11.7515 & & \\
\hline & Population size & -303.001 & 21.9892 & & \\
\hline & Population growth population size & -301.317 & 23.6733 & & \\
\hline & $\begin{array}{l}\text { Population growth }+ \text { population size }+ \\
\text { unemployment }\end{array}$ & -301.243 & 23.7476 & & \\
\hline & Intercept of values & -266.903 & 58.0875 & & \\
\hline & Population growth & -266.008 & 58.9828 & & \\
\hline & Unemployment & -265.217 & 59.7735 & & \\
\hline & Population growth + unemployment & -264.630 & 60.3605 & & \\
\hline Syphilis & Unemployment + income & -879.245 & 0 & 0.465195 & 0.43 \\
\hline & Population size + unemployment + income & -877.925 & 1.3198 & 0.240561 & 0.44 \\
\hline & $\begin{array}{l}\text { Population growth }+ \text { unemployment }+ \\
\text { income }\end{array}$ & -877.397 & 1.8481 & 0.18464 & 0.42 \\
\hline & $\begin{array}{l}\text { Population growth }+ \text { population size }+ \\
\text { unemployment + income }\end{array}$ & -875.976 & 3.2695 & & \\
\hline & Income & -871.049 & 8.1963 & & \\
\hline & Population size + income & -870.563 & 8.6818 & & \\
\hline & Population growth + income & -869.059 & 10.1865 & & \\
\hline & $\begin{array}{l}\text { Population growth }+ \text { population size }+ \\
\text { income }\end{array}$ & -868.672 & 10.5733 & & \\
\hline & Population size & -846.402 & 32.8431 & & \\
\hline & Population growth + population size & -844.457 & 34.7877 & & \\
\hline & $\begin{array}{l}\text { Population growth }+ \text { population size }+ \\
\text { unemployment }\end{array}$ & -843.496 & 35.7494 & & \\
\hline & Intercept of values & -812.970 & 66.2754 & & \\
\hline \multicolumn{6}{|c|}{${ }^{*} \mathrm{~W}_{\mathrm{i}}$ and $\mathrm{R}^{2}$ were calculated for only those models considered to be of best fit } \\
\hline
\end{tabular}




\begin{tabular}{|c|c|c|c|c|c|}
\hline & Model & AIC & $\triangle \mathrm{AIC}$ & Wi* & $\mathbf{R}^{2}$ \\
\hline & Population growth & -812.585 & 66.6605 & & \\
\hline & Unemployment & -811.029 & 68.2165 & & \\
\hline & Population growth + unemployment & -810.843 & 68.4023 & & \\
\hline \multirow[t]{15}{*}{ HIV } & Unemployment + income & -250.519 & 0 & 0.52521 & 0.37 \\
\hline & Population size + unemployment + income & -248.600 & 1.9192 & 0.20118 & 0.37 \\
\hline & $\begin{array}{l}\text { Population growth + unemployment + } \\
\text { income }\end{array}$ & -248.535 & 1.984 & 0.19477 & 0.37 \\
\hline & $\begin{array}{l}\text { Population growth }+ \text { population size }+ \\
\text { unemployment }+ \text { income }\end{array}$ & -246.604 & 3.9144 & & \\
\hline & Income & -239.578 & 10.9404 & & \\
\hline & Population size + income & -238.168 & 12.3504 & & \\
\hline & Population growth + income & -237.742 & 12.7764 & & \\
\hline & $\begin{array}{l}\text { Population growth }+ \text { population size }+ \\
\text { income }\end{array}$ & -236.476 & 14.0424 & & \\
\hline & Population size & -220.601 & 29.9180 & & \\
\hline & $\begin{array}{l}\text { Population growth }+ \text { population size }+ \\
\text { unemployment }\end{array}$ & -219.483 & 31.0360 & & \\
\hline & Population growth + population size & -218.810 & 31.7084 & & \\
\hline & Intercept of values & -197.583 & 52.9358 & & \\
\hline & Unemployment & -196.471 & 54.0479 & & \\
\hline & Population growth & -196.324 & 54.1943 & & \\
\hline & Population growth + unemployment & -195.626 & 54.8925 & & \\
\hline \multicolumn{6}{|c|}{${ }^{*} \mathrm{~W}_{\mathrm{i}}$ and $\mathrm{R}^{2}$ were calculated for only those models considered to be of best fit } \\
\hline \multicolumn{6}{|c|}{$\begin{array}{l}\text { Where } A I C \text { is Akaike Information Criterion value, } \triangle A I C \text { is the change in Akaike Information Criterion } \\
\text { value, } W_{i} \text { is the Akaike weights value, and } R^{2} \text { is the correlational coefficient. }\end{array}$} \\
\hline
\end{tabular}


Table 5

Akaike Information Criterion Model Averages

\begin{tabular}{|llllll|}
\hline & Intercept & $\begin{array}{l}\text { Population } \\
\text { growth }\end{array}$ & Unemployment & $\begin{array}{l}\text { Income } \\
\text { Population }\end{array}$ & $\begin{array}{l}\text { Pope } \\
\text { size }\end{array}$ \\
\hline $\begin{array}{l}\text { Chlamydia Beta } \\
\text { value }\end{array}$ & -0.34225 & 0.15206 & 0.01975 & 0.00001 & 0.00000 \\
\hline $\begin{array}{l}\text { Gonorrhea Beta } \\
\text { value }\end{array}$ & -0.20632 & -0.02705 & 0.01224 & 0.00001 & 0.00001 \\
\hline Syphilis Beta Value & -0.02206 & 0.00664 & 0.00108 & 0.00001 & 0.00001 \\
\hline HIV Beta Value & -0.34963 & 0.05205 & 0.02104 & 0.00001 & 0.00001 \\
\hline $\begin{array}{l}\text { The significance value is < } 0.05 \text { where all numbers represent standardized beta values between each } \\
\text { STI and each variable of consideration. }\end{array}$ & & & \\
\hline
\end{tabular}

